\title{
RESEARCH OF TRENDS OF DEVELOPMENT OF THE HEALTH INSURANCE MARKET IN THE CONDITIONS OF SOCIO-ECONOMIC CRISIS IN UKRAINE
}

\author{
L. Hala, H. Panfilova, O. Tsurikova
}

\begin{abstract}
Мета: проаналізувати тенденції розвитку ринку медичного страхування за умов соціально-економічноі кризи в Украӥні.

Матеріали і методи. У дослідженнях використовувалися дані Національної комісіӥ, щзо здійснює державне регулювання у сфері ринків фінансових послуг, та Ліги страхових організацій України за показниками діяльності страховиків (кількість укладених договорів, валові, чисті премії й виплати) за 20142018 роки. Нормування фінансових показників здійснювалося за макроекономічними стандартами, щчо були закладені у державних бюджетах у різні роки (мінімальна заробітна плата, прожитковий мінімум на одну працездатну особу, курс НБУ вартості 1 долара, вартість мінімального продуктового кошика). Використано історичний, аналітико-порівняльний, системний, логічний, гіпотетико-дедуктивний, математико-статистичний методи.
\end{abstract}

Результати дослідження. Математично доведена значущість зв'язків між усіма показниками, щзо характеризують страхову діяльність компаній з медичного страхування. Крім иъього, всі дані упродовж 2014-2018 рр. продемонстрували позитивну динаміку зростання, чого не можна стверджувати після проведення їх нормування до макроекономічних показників. За нормованими даними по мінімальній заробітній платні спостерігалось суттеве зниження показників у 2017 р. з незначним їх зростанням за даними 2018 р. Позитивним виглядає планомірне упродовж 2014-2018 рр. зростання фінансових показників, щзо пронормовані за прожитковим мінімумом (для працездатних осіб). Стрімке падіння значень всіх фінансових показників, пронормованих за курсом долара спостерігалось у 2015 р., щзо є наслідком кардинальних змін у грошово-кредитній політиці в країні. Мінімального значення зазначені показники досягли у 2016 р. За показниками, щзо пронормовані за вартістю мінімального продуктового кошика, по всіх показниках спостерігався зигзагоподібний характер змін, з різким падінням даних у 2016 р. та наступним їх зростанням вже у 2017 р. Усі показники, щчо були пронормовані за мінімальною заробітною платою, курсом НБУ вартості долара, вартістю мінімального продуктового кошика у 2018 р., так й не досягли значень, щчо були характерні для 2014 p.

Висновки. Ринок медичного страхування характеризувався складністю розвитку та залежністю від основних макроекономічних показників, які використовуються у розрахунку багатьох соціально важливих показників розвитку суспільства. Негативні тендениії розвитку сегменту ринку медичного страхування були обумовлені безпосереднім або відтермінованим у часі впливом тих змін, щзо спостерігалися в макроекономічному середовищі в період сочіально-економічної кризи

Ключові слова: ринок медичного страхування, страхові премії, страхові виплати, рівень страхових виплат, медичне страхування

\section{Introduction}

During the years of Ukraine's independence, the financial market has developed despite adverse political crises and economic turmoil, lack of consistent public policy, lack of confidence in financial institutions, etc. $[1,2]$. An important component of any state's financial market is the health insurance market (HI), which performs important socially-oriented functions, in particular allowing for the formation and implementation of reliable financial protection of the population in the case of loss of health, which is of the highest social value in the country [3,4]. Analyzing the data of the specialized literature, it can be argued that the issues of analysis of the domestic market of the HI in the context of the de- velopment of financial relations, society as a whole and processes of state formation were considered in the works of scientists from different positions. Thus, the most powerful in terms of the conducted research are the scientific schools of economists, whose work presents the results of the analysis of the main macroeconomic indicators of the development of the domestic market of HI [1, 5], comparison of existing approaches in the organization of insurance activities and features of the development of the HI in Ukraine [6], and also mechanisms of state regulation of the specified form of financial activity in the country [7].

Considering the socio-economic importance of HI developing on the path of building stable social 
relations and increasing the availability of medical and pharmaceutical services for different segments of the population, it is interesting to look at the profile of foreign publications on this topic. Thus, an important role in the work of foreign authors is given to a critical analysis of the development of $\mathrm{HI}$ in the context of the development of health care systems in developing countries $[8,9]$ and increasing the impact of risks on the effectiveness of insurance relations in the market of medical and pharmaceutical services [10]. Particularly noteworthy are the works in which the authors analyze the problems and prospects of the relationship between employers and insured persons under the agreements of collective (corporate) or mandatory HI (MHI) public servants $[11,12]$. Issues of development of the HI market, current tendencies of its transformation into social relations between different social groups of the population are presented in the works of economists $[13,14]$. It is impossible to note the relevance of the works, which consider the issues of peculiarities of tariff policy formation and introduction of an innovative model of relations between insurer and insured on the verge of purely medical and socioeconomic problems [15]. For example, in the formation of insurance relationships between insurance companies operating under market relations and patients with mental disorders [16], patients who expect to have planned medical interventions, etc. [17]. The high market risks of conducting insurance operations in these groups of population cause insufficient level of accessibility to HI programs, so consideration of the peculiarities of forming a socially and ethically oriented tariff policy in the HI market in this direction deserves attention from state institutions [18, 19].

Considering the level of public expectations for the implementation of systemic transformations in different spheres of political and public life in Ukraine, first of all increase the level of accessibility of medical and pharmaceutical services to citizens, regardless of their social and material status, are of particular importance to the work of foreign authors, who consider the issues of the development of micro-insurance programs for the poorest [20, 21]. According to experts, the development of micro-insurance programs for the population in case of loss of health is now considered as one of the most promising ways of solving the painful problems of increasing the level of accessibility of medical and pharmaceutical services in developing countries [22, 23]. Systematizing the above, it can be argued that HI, as a specific and simultaneously socially and ethically oriented form of insurance activity in the works of modern scientists is considered in a wide range of problems in the areas. At the same time, given the permanent growth of the population's needs in the direction of providing effective and affordable medical and pharmaceutical care, the question of analyzing the impact of various factors on the state of development of the HI market emerges as a pressing issue on the path of harmonious development of society.

Despite the lack of a consistent position of the government of Ukraine in the recent years regarding the implementation of insurance relations in health care, such as Germany, the issue of developing ration al models of relations between different actors in the provision of medical and pharmaceutical assistance to the population of the Ukrainian insurance market is important and social. Given the social importance of HI for maintaining social stability in society, issues of analysis and problems of development of the domestic market of HI in the conditions of political and socioeconomic crisis, which began in the country since 2014, have become especially relevant.

The purpose of the study is to analyze trends in the development of the HI market in Ukraine in the face of the socio-economic crisis that has been ongoing in the country since 2014 .

\section{Planning (methodology) of research}

In the first stage of the work, according to its purpose, it was necessary to outline the subject and the main objects of the research. The subject of research has been the processes and approaches that have formed in the domestic HI market in the conditions of financial and socio-economic crisis in the country. We have identified the main indicators that characterize the financial position of Ukrainian insurance companies that perform HI. First of all, it is: the number of contracts concluded; gross insurance premiums and payments; net insurance premiums and payments. In order to assess the impact of the socio-economic crisis on the state of development of the HI market, we also selected macroeconomic indicators that affect the well-being of the population for analysis. This is the minimum wage, a subsistence minimum for one able-bodied person per month, the National Bank of Ukraine (NBU) rate of 1USD exchange at the beginning of the year, and the cost of a minimum grocery basket. These data are used in the calculations of a wide range of important socio-economic indicators. For example, the minimum wage is a social standard, the effective implementation of which provides for a sufficient standard of living and contributes to the development of human capital in the country as a whole $[1,2]$.

In the second stage we have been tasked with mathematically determining the significance of the relationships between indicators that characterize the state of development of the HI market, as well as investigate the main trends of their changes in accordance with the normalization of the basic macroeconomic data that determine the well-being of the population of the country during 2014-2018. To solve these problems of research it was necessary to choose the appropriate mathematical apparatus. It is known that for quantitative data, the most common criterion for estimating statistical coupling is the paired correlation coefficient, or Pearson's coefficient, and the Student's criterion for normal distribution of values of random variables is the main parameter of its significance [24]. These indicators were used in the studies.

The following was the normalization (by standard) of financial indicators of the development of the domestic HI market to macroeconomic indicators (minimum wage, living wage for one able-bodied person per month, the National Bank of Ukraine (NBU) rate of 1USD exchange at the beginning of the year and the cost of the minimum grocery basket) : 


$$
x_{i j}^{\text {норм }}=\frac{x_{i j}}{M_{k j}}[24] \text {, }
$$

where $x_{i j}, x_{i j}^{\text {norm }}$ - the value of the $\mathrm{i}$ sign in the $\mathrm{j}$ year before and after normalization, respectively; $M_{k j}-$ the value of the $\mathrm{k}$ macroeconomic indicator in the $\mathrm{j}$ year.

The third stage of the research became effective, that is, during its conduct it was necessary to analyze the nature of the links between the selected financial data of the development of the HI market in Ukraine. An important stage of our research was also the analysis of the dynamics of financial indicators of the development of the HI market before and after adjusting for selected macroeconomic indicators related to the formation of welfare and solvency of the population of Ukraine.

The fourth stage of the research aimed to identify the main characteristics, problems and tendencies of the development of the domestic HI market and to outline the directions of its further development. In addition, objective constraints on the practical use of the research findings needed to be identified.

\section{Materials and methods}

In accordance with the stated purpose, subject and objects of the analysis, the materials presented on the official sites of the National Commission for state regulation in the field of financial services and the League of Insurance Organizations of Ukraine were examined. Indicators characterizing the state of development of the domestic HI market in the dynamics of years are presented in Table 1.

In the Table 2 are presented indicators by which the standardization of characteristics was performed according to the standard, as the values of macroeconomic indicators by years were selected.

Table 1

The main indicators characterizing the state of development of the domestic HI market for 2014-2018

\begin{tabular}{|c|c|c|c|c|}
\hline \multicolumn{5}{|c|}{ Indicators of analysis by years } \\
\hline 2014 & 2015 & 2016 & 2017 & 2018 \\
\hline \multicolumn{5}{|c|}{ Number of concluded contracts, units } \\
\hline 5861402 & 4537625 & 6106402 & 10655040 & 12086732 \\
\hline \multicolumn{5}{|c|}{ Gross insurance premiums, thous. UAH } \\
\hline 2265692.3 & 2689432.7 & 3375087.3 & 4177399.0 & 5324439.7 \\
\hline \multicolumn{5}{|c|}{ Gross insurance payments, thous. UAH } \\
\hline 1289053.1 & 1415121.1 & 1581833.3 & 1968096.6 & 2441661.9 \\
\hline \multicolumn{5}{|c|}{ Net insurance premiums, thous. UAH } \\
\hline 2129758.4 & 2596996.5 & 3241937.5 & 3901975.6 & 4815682.8 \\
\hline \multicolumn{5}{|c|}{ Net insurance payments, thous. UAH } \\
\hline 1287943.4 & 1414333.9 & 1579757.4 & 1965578.2 & 2439807.1 \\
\hline
\end{tabular}

Table 2

Macroeconomic indicators used in the studies

\begin{tabular}{|c|c|c|c|c|}
\hline \multicolumn{5}{|c|}{ Macroeconomic indicators by years } \\
\hline 2014 & 2015 & 2016 & 2017 & 2018 \\
\hline \multicolumn{5}{|c|}{ Minimum monthly wage, UAH } \\
\hline 1218.00 & 1218.00 & 1378.00 & 3200.00 & 3723.00 \\
\hline \multicolumn{5}{|c|}{ Subsistence minimum per person per month from January 1 (for able-bodied persons), UAH } \\
\hline 1218.00 & 1218.00 & 1378.00 & 1600.00 & 1762.00 \\
\hline \multicolumn{5}{|c|}{ The NBU rate of 1USD exchange at the beginning of the year, UAH } \\
\hline 7.9930 & 15.7686 & 23.7837 & 26.6924 & 28.0672 \\
\hline \multicolumn{5}{|c|}{ Cost of minimum grocery basket, UAH } \\
\hline 517.00 & 636.00 & 912.00 & 976.00 & 1524.00 \\
\hline
\end{tabular}

These indicators were presented in the Law of Ukraine "On the State Budget of Ukraine for 2018" of 7.12.2017 No. 2246-VIII, Laws of Ukraine "On the State Budget of Ukraine for 2017" of 21.12.2016, No. 1801VIII, Laws Of Ukraine "On the State Budget of Ukraine for 2016" of December 25, 2015 No. 928-VII, Laws of Ukraine "On the State Budget of Ukraine for 2015" of December 28, 2014 No. 80-VIII, Laws of Ukraine "On the State Budget of Ukraine for 2014» of January 16, 2014 № 719-VII

In addition to these indicators, the work used data of legal acts regulating insurance activities in the country, as well as special literature on the subject of research. The historical, analytical, comparative, systemic, logical, hypothetical-deductive, mathematical-statistical methods of scientific search and cognition were used. 
Statistical data processing was performed using standard statistical analysis packages Statistica (version 12.0, StatSoft, Tulsa, USA) and Excel spreadsheet. A p-value $<0.05$ was considered statistically significant.

\section{Results of the research}

According to the results of the study it is mathematically proved that all financial indicators showed the importance of relations as one another (Table 3).

Table 3

Analysis of the significance of the relationship between the indicators that characterize the development of the domestic HI market

\begin{tabular}{|c|c|c|c|c|c|}
\hline $\begin{array}{c}\text { Indicators of anal- } \\
\text { ysis }\end{array}$ & $\begin{array}{l}\text { Number of con- } \\
\text { cluded contracts }\end{array}$ & $\begin{array}{c}\text { Gross insurance } \\
\text { premiums }\end{array}$ & $\begin{array}{c}\text { Gross insurance } \\
\text { payments }\end{array}$ & $\begin{array}{c}\text { Net insurance } \\
\text { premiums }\end{array}$ & $\begin{array}{c}\text { Net insurance } \\
\text { payments }\end{array}$ \\
\hline \multirow[b]{2}{*}{$\begin{array}{l}\text { Number of con- } \\
\text { cluded contracts }\end{array}$} & $\mathrm{p}=---$ & $\mathrm{p}=0.043$ & $\mathrm{p}=0.028$ & $\mathrm{p}=0.050$ & $\mathrm{p}=0.028$ \\
\hline & - & $\begin{array}{l}\text { Significant con- } \\
\text { nection }\end{array}$ & $\begin{array}{l}\text { Significant con- } \\
\text { nection }\end{array}$ & $\begin{array}{l}\text { Significant } \\
\text { connection }\end{array}$ & $\begin{array}{l}\text { Significant } \\
\text { connection }\end{array}$ \\
\hline \multirow[b]{2}{*}{$\begin{array}{l}\text { Gross insurance } \\
\text { premiums }\end{array}$} & $\mathrm{p}=0.043$ & $p=---$ & $\mathrm{p}=0.002$ & $\mathrm{p}=0.000$ & $\mathrm{p}=0.002$ \\
\hline & $\begin{array}{l}\text { Significant connec- } \\
\text { tion }\end{array}$ & - & $\begin{array}{c}\text { Significant con- } \\
\text { nection }\end{array}$ & $\begin{array}{l}\text { Significant } \\
\text { connection }\end{array}$ & $\begin{array}{l}\text { Significant } \\
\text { connection }\end{array}$ \\
\hline \multirow{2}{*}{$\begin{array}{l}\text { Gross insurance } \\
\text { payments }\end{array}$} & $\mathrm{p}=0.028$ & $\mathrm{p}=0.002$ & $p=---$ & $\mathrm{p}=0.004$ & $\mathrm{p}=0.000$ \\
\hline & $\begin{array}{l}\text { Significant connec- } \\
\text { tion }\end{array}$ & $\begin{array}{c}\text { Significant con- } \\
\text { nection }\end{array}$ & - & $\begin{array}{l}\text { Significant } \\
\text { connection }\end{array}$ & $\begin{array}{l}\text { Significant } \\
\text { connection }\end{array}$ \\
\hline \multirow{2}{*}{$\begin{array}{l}\text { Net insurance } \\
\text { premiums }\end{array}$} & $\mathrm{p}=0.050$ & $\mathrm{p}=0.000$ & $\mathrm{p}=0.004$ & $\mathrm{p}=---$ & $\mathrm{p}=0.004$ \\
\hline & $\begin{array}{l}\text { Significant connec- } \\
\text { tion }\end{array}$ & $\begin{array}{c}\text { Significant con- } \\
\text { nection }\end{array}$ & $\begin{array}{c}\text { Significant con- } \\
\text { nection }\end{array}$ & - & $\begin{array}{l}\text { Significant } \\
\text { connection }\end{array}$ \\
\hline \multirow{2}{*}{$\begin{array}{l}\text { Net insurance } \\
\text { payments }\end{array}$} & $\mathrm{p}=0.028$ & $\mathrm{p}=0.002$ & $\mathrm{p}=0.000$ & $\mathrm{p}=0.004$ & $p=---$ \\
\hline & $\begin{array}{l}\text { Significant connec- } \\
\text { tion }\end{array}$ & $\begin{array}{c}\text { Significant con- } \\
\text { nection }\end{array}$ & $\begin{array}{c}\text { Significant con- } \\
\text { nection }\end{array}$ & $\begin{array}{l}\text { Significant } \\
\text { connection }\end{array}$ & - \\
\hline
\end{tabular}

Next, we are tasked with analyzing the dynamics of data changes that characterize the state of development of the domestic HI market before and after normalization relative to the macroeconomic indicators selected for analysis. It was determined that during 2014-2018, with- out any exceptions, financial indicators characterizing the state of $\mathrm{HI}$ insurance business activity had a systematic increase, reaching a maximum in 2018. An example of the dynamics of one of the indicators (gross insurance premiums, Thous. UAH) is shown in Fig. 1.

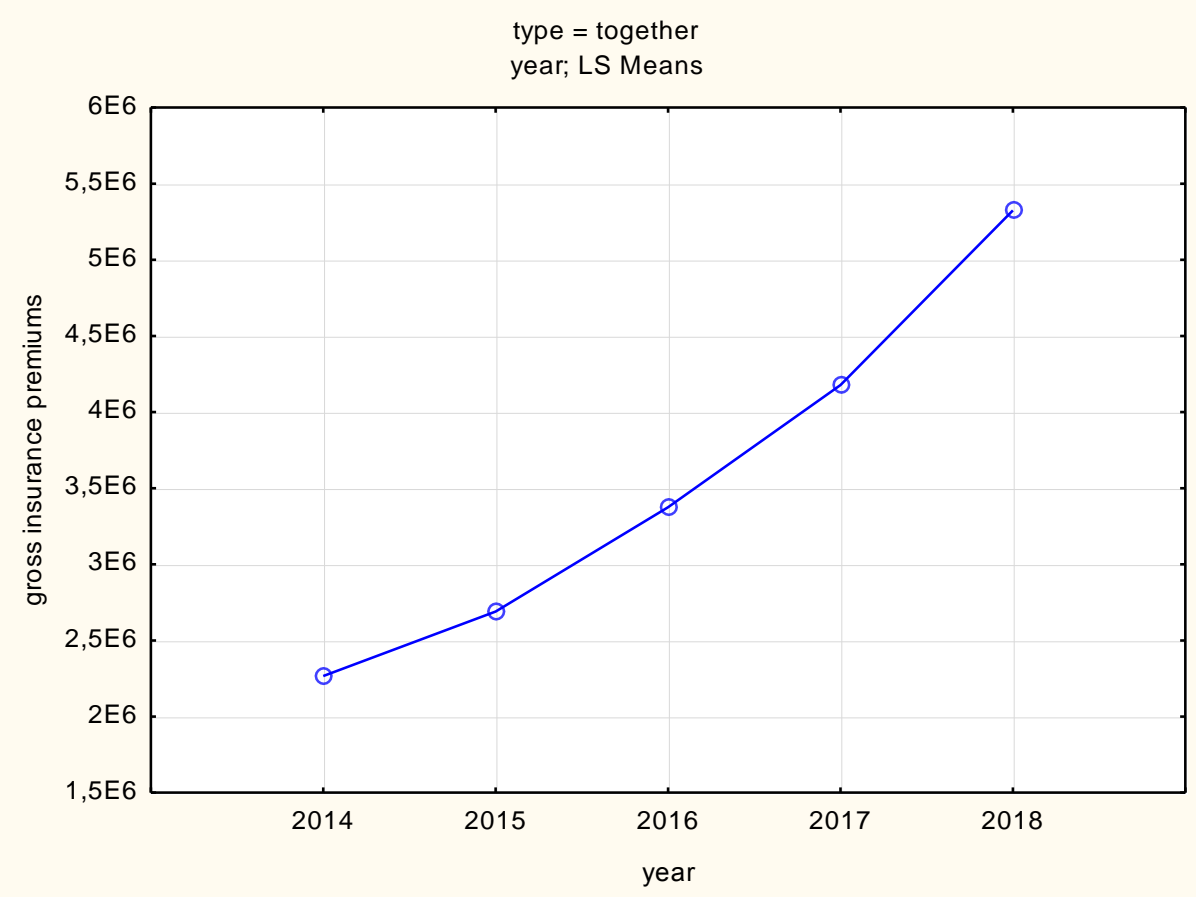

Fig. 1. Analysis of the dynamics of changes in cc in the dynamics of years (non-adjusted figures)

Considering the consequences of the political, financial and socio-economic crisis in Ukraine, it is interesting to analyze the financial data of the devel- opment of the domestic HI market, which are normalized to the macroeconomic indicators selected for the experiment. 
Normalization with the lowest wages in monthly amount

Gross and net insurance premiums, normalized by the aforementioned indicator, showed a gradual increase over the 2014-2016 period. Gross and net insurance payments had a slightly different nature of change, so growth was observed only from 2014 to 2015 . Already in 2016, these indicators saw a gradual decrease to the minimum values for the sample of indicators in 2017. This year also saw a significant decrease in gross and net insurance premiums. That is, since 2016, insurance companies have started to adopt a more restrained, financially speaking, policy of payments to insured persons under insurance contracts. In 2018, there was a gradual increase in all indicators, but they did not reach 2014 values. That is, given the fact that the crisis in the financial market of Ukraine was observed during 2014-2015, the insurance segment of the market with HI under these conditions showed a relative inertia to negative changes (20142016), and have already taken place in 2017.

Normalization with the subsistence minimum per person per month from January 1 (for able-bodied persons), $U A H$

According to the indicators, normalized by the subsistence minimum for one able-bodied person per month, it is established that the dynamics of gross and net insurance premiums is characterized by a systematic increase. That is, insurance companies have steadily accumulated insurance premiums throughout the study period in accordance with the terms of contracts concluded with insurers. The situation is different in terms of gross and net payments. Thus, according to the indicators during 2014-2015, there was an increase in data with their gradual decrease in 2016. Positive, in the future, was their growth during 2017-2018. Thus, it can be concluded that there are negative trends for the working population for the size of insurance payments (gross and net) due to loss of health was unstable, which significantly reduces the level of public confidence in HI operations in the financial crisis.

Normalization with the exchange rate of $N B U$ of IUSD at the beginning of the year

The HI market, as a component of the financial market, depends on the monetary policy implemented in the state by NBU. During the years of independence, the national currency has undergone many critical moments of development, but the biggest shocks in the financial market of the country were observed in 2014-2016. Thus, at the beginning of 2014 the value of USD 1 was 7.99 UAH, at the end of that year it dropped to
15.77 UAH. In February 2015, the NBU decided to abandon the fixed rate policy that had been in place since the introduction of the national currency in 1996. This led to the formation of the so-called "hryvnia exchange rate", which was determined by the results of trading on the interbank foreign exchange market. Due to the whole complex of factors, on February 26, 2015 , the national currency rate reached its historical minimum for the whole history of the country and equalled 30.01 UAH per 1 USD. Then the process of gradual strengthening of the hryvnia exchange rate began and as of early 2016, 1 USD was worth 24.00 UAH, and as of August 1, 2016 it amounted to 26.08 UAH. The financial turmoil in the country forced the NBU to return as a regulator to foreign exchange interventions, which led to a relative stabilization of key indicators in the foreign exchange market [19].

Dynamics of financial indicators, standardized at the NBU's national rate of 1 USD, showed a characteristic for all without exception indicators of sharp decline in 2015, which continued in 2016. This year, all financial indicators, normalized at the NBU rate, reached their minimum value. That is, despite the planned growth of all financial indicators during 2014-2018, the segment of the HI insurance market against the background of the depreciation of the national currency has repeatedly experienced significant shocks in 2016. During 2017-2018, the market situation stabilized somewhat and financial indicators became gradually grow. At the same time, the highest growth rates were characteristic of gross and net insurance premiums.

\section{Normalization with the value of the minimum grocery basket}

Interesting are the results of the analysis of the dynamics of financial indicators that have been normalized to the value of the minimum grocery basket. By this indicator, all financial indicators showed a zigzag character of the dynamics of data changes. Thus, since 2014, all normalized indicators have been characterized by a sharp decrease in data, which reached their minimum value in 2016. In 2017, against the background of relative stabilization of financial indicators in the country and a slight increase in the level of well-being of the population of the country, all normalized financial indicators showed an increase, but unfortunately this trend was not preserved in the future. In 2018, all indicators were characterized by a decrease in digital data to the minimum values for the entire observation period. As an example, in Fig. 2 and 3 present the analysis of the dynamics of net insurance premiums and payments. 


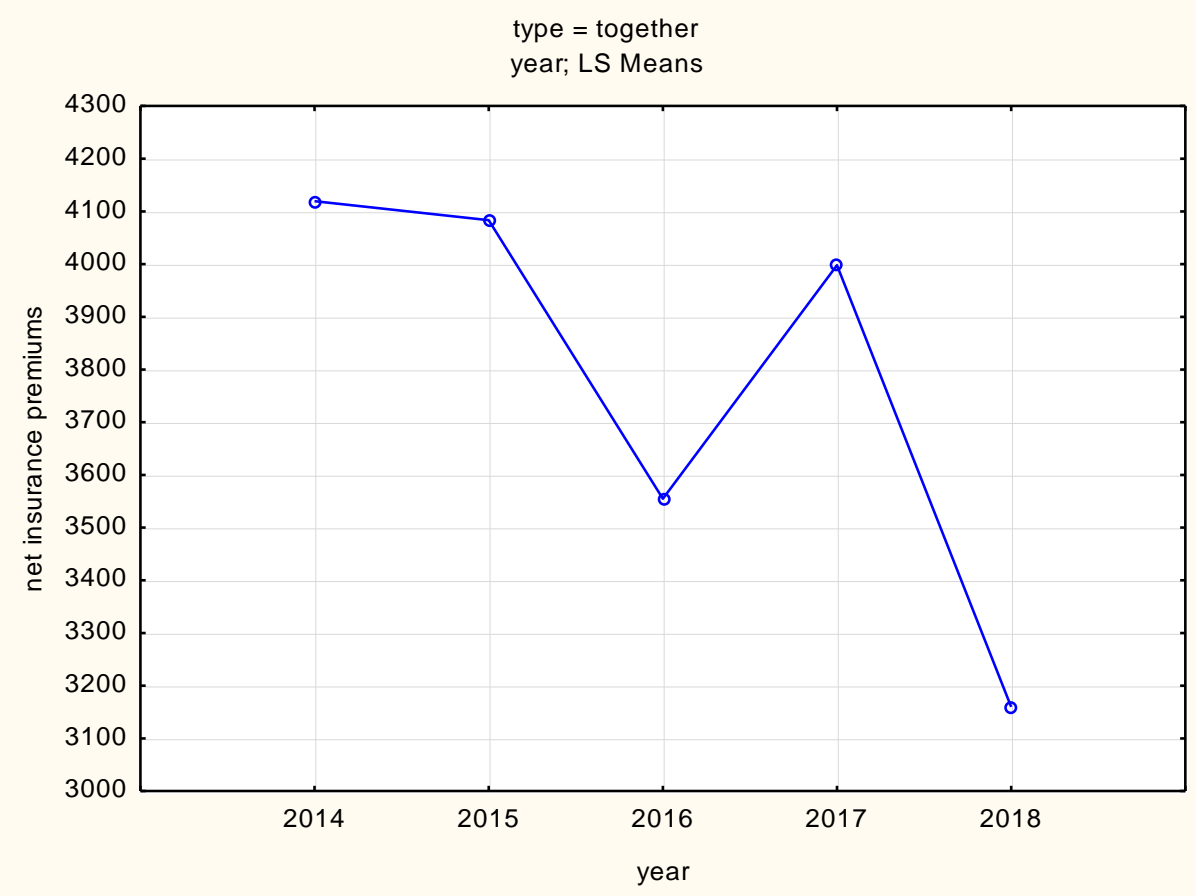

Fig. 2. Analysis of the dynamics of net insurance premiums (valuation of the minimum product basket)

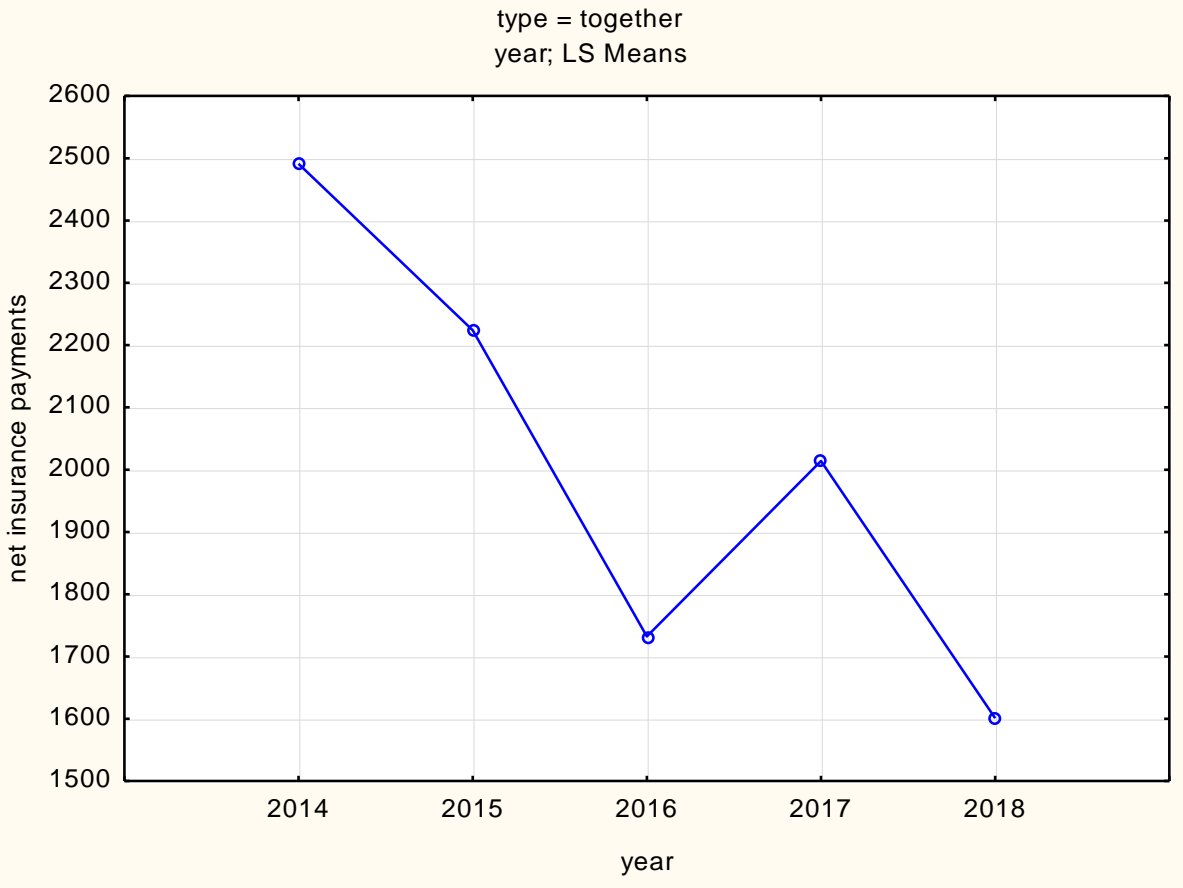

Fig. 3. Analysis of the dynamics of net insurance payments (normalization by the value of the minimum grocery basket)

As a whole, it can be noted that despite the positive tendencies of monthly growth in the minimum wage, the NBU exchange rate of 1 USD, the value of the minimum grocery basket, no financial indicator in 2018 reached the 2014 values. Only indicators, which were normalized by the subsistence minimum per able-bodied person in 2018, differed in data growth relative to 2014. This fact indicates the dominance of negative trends in the impact of major macroeconomic indicators that determine the well-being of the population on the state of development of the domestic market HI.

\section{Discussion of the results}

At the end of the research, it should be noted that the results of the research do not fall within the scope of objective contradictions with the work of scientists on the subject. The presented results only state the state of the situation by one or another type of insurance activity in the dynamics of years. It also aims at outlining the direction of future research, namely, conducting factor analysis on individual insurance products offered in the domestic HI market.

In order to form an effective state policy in the field of regulating the insurance market with $\mathrm{HI}$ in 
Ukraine, in our opinion, it is necessary to determine the results that are most important and least significant from the point of their theoretical and applied value. Yes, the most significant are the significant links between all indicators that characterize the insurance business of $\mathrm{HI}$ companies. In addition, given the rapid devaluation of the national currency since 2014, the increasing nature of changes in all financial indicators in the hryvnia equivalent in the period from 2014 to 2018 is expected. The most socially significant results are data from the analysis of the dynamics of indicators, which were normalized to the socially important macroeconomic parameters in the country. The mathematically complex nature of the dynamics of changes in the normalized financial indicators in the conditions of the financial and economic crisis in society requires the development and implementation of socially adapted HI market regulation mechanisms by the state. In addition, mechanisms of direct and indirect impact on financial stability and as a consequence of the competitiveness of insurance companies need to be introduced in a broader range of areas. In these circumstances, an important area of prospective research will be to analyze the main factors that directly affect the various financial indicators of insurance companies and identify the main ways to increase the level of positive attitude of the population to HI programs. It is necessary to mention separately the objective limitations in conducting our research and practical use of the obtained results. In our studies we used data on all $\mathrm{HI}$ insurance operations in general. It should be noted that during the years 20142018, the insurance companies carried out operations on such types of insurance as "continuous health insurance", "health insurance in case of illness" and "insurance of medical expenses". According to these types of HI, insurance companies offer different products that are significantly different from each other in the whole range of parameters $[1,25]$.

Limitations of the study. The main limitations on the use and interpretation of the results we present are as follows. First, the analysis of the indicators characterizing the state of development of the HI market during 2014-2018 was carried out at the current prices for a specific period of time, without taking into account the relevant inflation index activity in the country. Taking into account the fact that during 2014-2015 there was an unstable situation in the financial market of Ukraine, it would be expedient to analyze the dynamics of changes in indicators presented at comparable prices to the data of the "pre-crisis" 2013. Secondly, the next limitation in the interpretation of the results obtained in the practical plane of development of the HI market is due to the design of the research we conducted. Yes, the results of studies on different types of HI need to be systematized at separately determined time intervals. This will allow to characterize among themselves different types of HIs, to determine the peculiarities of their development in accordance with those or other periods of development of the Ukrainian insurance market segment under study. On this basis, the following limitation of the conducted analysis of the development of the HI market crystallizes, namely the absence of a proven link between the state of the HI market development and the external factors affecting the organization of insurance activity in the country.

Prospects for further research. In view of the above, we consider it necessary to point out that an analysis of the dynamics of insurers' financial data, normalized by the relevant macroeconomic indicators for different types of HIs and products offered in the relevant segment of the Ukrainian insurance market, will be a promising direction for our further. Identifying the specific trends in the development of a particular segment of the HI market will allow to develop directions for improving the performance of insurers in such an important, from a socio-economic point of view, a segment, such as HI.

\section{Conclusions}

The segment of the domestic insurance market in which HI operations are carried out was characterized by complexity of development and dependence on the basic macroeconomic indicators used in the calculations of many socially significant indicators of social development. The negative trends in the development of the HI market segment were due to the direct or delayed impact of the changes observed in the macroeconomic environment during the socio-economic crisis.

\section{Conflict of interests}

There is no conflict of interest.

\section{References}

1. Voronenko, Yu. V., Moskalenko, V. F. (2000). Sotsialna medytsyna ta orhanizatsiia okhorony zdorovia. Ternopil: Ukrmedknyha, 680 .

2. Bazylevych, V. D., Filoniuk, O. F., Bazylevych, K. S. et. al.; Bazylevych, V. D. (Ed.) (2008). Strakhuvannia. Kyiv: Znannia-Pres, 1019.

3. Rao, S. (2004). Health insurance concepts, issues and challenges. Economic and Political Weekly, 39, 3835-3844.

4. Dong, W. (2006). Can health care financing policy be emulated? The Singaporean medical savings accounts model and its Shanghai replica. Journal of Public Health, 28 (3), 209-214. doi: http://doi.org/10.1093/pubmed/fdl023

5. Hamankova, O. O. (2009). Rynok strakhovykh posluh Ukrainy: teoriia, metodolohiia, praktyka. Kyiv: KNEU, 283.

6. Danylchenko, L. (2017). The study of features and prospects of the insurance medicine in Ukraine in modern conditions. ScienceRise: Medical Science, 3 (11), 9-15. doi: http://doi.org/10.15587/2519-4798.2017.96222

7. Nahaichuk, N. H. (2006). Formuvannia systemy dobrovilnoho medychnoho strakhuvannia v umovakh rynkovoi ekonomiky. Kyiv.

8. Odeyemi, I., Nixon, J. (2013). The role and uptake of private health insurance in different health care systems: are there lessons for developing countries? ClinicoEconomics and Outcomes Research, 5, 109-118. doi: http://doi.org/10.2147/ceor.s40386

9. Sekhri, N., Savedoff, W. (2005). Private health insurance: implications for developing countries. Bulletin of the World Health Organization, 83, 127-134. 
10. Kairies-Schwarz, N., Kokot, J., Vomhof, M., Weßling, J. (2017). Health insurance choice and risk preferences under cumulative prospect theory - an experiment. Journal of Economic Behavior \& Organization, 137, 374-397. doi: http://doi.org/10.1016/j.jebo.2017.03.012

11. Liu, Y., Jin, G. Z. (2015). Employer contribution and premium growth in health insurance. Journal of Health Economics, 39, 228-247. doi: http://doi.org/10.1016/j.jhealeco.2014.08.006

12. Shoven, J. B., Slavov, S. N. (2014). The role of retiree health insurance in the early retirement of public sector employees. Journal of Health Economics, 38, 99-108. doi: http://doi.org/10.1016/j.jhealeco.2014.03.013

13. Bolhaar, J., Lindeboom, M., van der Klaauw, B. (2012). A dynamic analysis of the demand for health insurance and health care. European Economic Review, 56 (4), 669-690. doi: http://doi.org/10.1016/j.euroecorev.2012.03.002

14. Liu, K. (2016). Insuring against health shocks: Health insurance and household choices. Journal of Health Economics, 46, 16-32. doi: http://doi.org/10.1016/j.jhealeco.2016.01.002

15. McDonald, E. M., Frattaroli, S., Edsall Kromm, E., Ma, X., Pike, M., Holtgrave, D. (2012). Improvements in Health Behaviors and Health Status Among Newly Insured Members of an Innovative Health Access Plan. Journal of Community Health, 38 (2), 301-309. doi: http://doi.org/10.1007/s10900-012-9615-3

16. Leach, L. S., Butterworth, P., Whiteford, H. (2012). Private health insurance, mental health and service use in Australia. Australian \& New Zealand Journal of Psychiatry, 46 (5), 468-475. doi: http://doi.org/10.1177/0004867411434713

17. Johar, M., Jones, G., Keane, M., Savage, E., Stavrunova, O. (2011). Waiting times for elective surgery and the decision to buy private health insurance. Health Economics, 20 (S1), 68-86. doi: http://doi.org/10.1002/hec.1707

18. McLeod, H., Grobler, P. (2009). The role of risk equalization in moving from voluntary private health insurance to mandatory coverage: the experience in South Africa. Advances in Health Economics and Health Services Research, 21, 159-196. doi: http://doi.org/10.1108/s0731-2199(2009)0000021010

19. Kasule, O. H. K. (2012). Health insurance and the ethical issue of equity. Journal of Taibah University Medical Sciences, 7 (2), 61-68. doi: http://doi.org/10.1016/j.jtumed.2012.10.003

20. The role of micro-health insurance in systems of Universal Health Coverage in developing countries: peer review of practices. Round table, 2015. Available at: http://fondation-sanofi-espoir.com/download/2015-12-09-mutuelles/TABLE_RONDE_UK.pdf

21. Dror, D. M., Koren, R., Steinberg, D. M. (2006). The impact of filipino micro health-insurance units on income-related equality of access to healthcare. Health Policy, 77 (3), 304-317. doi: http://doi.org/10.1016/j.healthpol.2005.08.001

22. Habib, S. S., Perveen, S., Khuwaja, H. M. A. (2016). The role of micro health insurance in providing financial risk protection in developing countries- a systematic review. BMC Public Health, 16 (1). doi: http://doi.org/10.1186/s12889-016-2937-9

23. Leppert, G., Ouedraogo, L.-M. (2012). Handbook of Micro Health Insurance in Africa. LIT Verlag Münster, 1, $48-59$.

24. Fang, J.-Q. (Ed.) (2017). Handbook of Medical Statistics. China: Sun Yat-Sen University. doi: http://doi.org/10.1142/10259

25. Vaithianathan, R. (2004). A Critique of the Private Health Insurance Regulations. The Australian Economic Review, 37 (3), 257-270. doi: http://doi.org/10.1111/j.1467-8462.2004.00328.x

Received date 03.09.2019

Accepted date 16.09.2019

Published date 31.10.2019

Liliia Hala, $\mathrm{PhD}$, Associate Professor, Department of Organization and Economics of Pharmacy, Bogomolets National Medical University, T. Shevchenko blvd., 13, Kyiv, Ukraine, 01601

E-mail: hala.liliia@gmail.com

Hanna Panfilova, Doctor of Pharmaceutical Sciences, Professor, Department of Organization and Economics of Pharmacy, National University of Pharmacy, Pushkinska str., 53, Kharkiv, Ukraine, 61002 E-mail: panf-al@ukr.net

Oksana Tsurikova, PhD, Assistant, Department of Quality Management, National University of Pharmacy Pushkinska str., 53, Kharkiv, Ukraine, 61002 